\title{
DOES A DEVELOPED COUNTRY MEAN HAPPY PEOPLE?
}

In Happiness And Contemporary Society : Conference Proceedings Volume (Lviv, March, 20-21, 2021). Lviv: SPOLOM, 2021. P. 137-139. https://doi.org/10.31108/7.2021.30

ISBN 978-966-919-697-2 
https://doi.org/10.31108/7.2021.30

\author{
HOXHAJ Meleq \\ Professional Master in Banking and Finance \\ Department of Banking and Finance, Epoka University (Tirana Albania)
}

DOES A DEVELOPED COUNTRY MEAN HAPPY PEOPLE?

It is often heard to discuss the economic development of a country and even more often to discuss economic growth but is economic growth enough to bring happiness? Economic growth and development is not enough at all if it is not accompanied by an improvement in the quality of life. Per capita income, freedom, inequality, infant mortality rate, corruption level, pollution level, food quality, air quality, water quality are some of the important factors that determine the quality of life. Only in a society with a high level of quality of life, we can talk about happy people, happiness which mostly comes from the psychological and social factors of a society.

Key Words: Economic development, happiness, sustainable development, quality of life.

$\checkmark$ Economic Development

$\checkmark$ Economic development is the primary objective of most nations in the world. One of the key factors to consider when analysing development is population dynamics.

$\checkmark$ When we talk about an intuitively developed country we think of:

$\checkmark$ A society of well-dressed, educated and well-nourished people.

$\checkmark$ A company that has access to almost all goods and services.

$\checkmark$ A society where people live in a healthy environment.

$\checkmark$ A society where the rights of the members of the society are respected.

$\checkmark$ A society with low crime rates, etc.

Economic development includes the processes and policies by which a nation improves its economic, political, and social well-being. This includes adjustments to a number of indicators such as: education level, life expectancy indicators, poverty rates, environmental conditions, etc. Economic development attaches importance to GDP / capita, taking into account other indicators that indicate the quality of life, such as: access to education, access to health, income distribution, environmental quality, etc. To identify economic development it is not enough to consider only GDP / capita, although the latter reflects the average income of a country does not provide information about the distribution of income also does not take into account environmental pollution etc. therefore we take into review other indicators as well. Prior to 2008 South Africa had a GDP / capita about 7 times higher than China, but infant mortality in South Africa was many times higher than in China. This variable indirectly tells a lot about the quality of life because babies and children under the age of 5 are quite sensitive to malnutrition, lack of hygiene, poor environmental conditions, etc. Infant mortality serves as an indicator for measuring economic development. Although South Africa had a higher GDP / spirit than China, it cannot be said that it had a higher economic development than China.

$\checkmark$ Some indicators used to assess the economic development of a country: 
$\checkmark$ Gross National Income (GNI) per capita: represents the dollar value of a country's final income in a year, divided by the country's population. The GNI / spirit of a country is closely linked to other indicators that measure the social and economic well-being of a country and its population. For example, people who live in places with high GNI / spirit have a longer life expectancy, the percentage of educated people is higher, people have access to safe water, the mortality rate is lower.

$\checkmark$ Percentage of income derived from the agricultural sector (what \% of GDP is income from this sector): the lower the income originating from the agricultural sector, the more developed a country's economy is.

$\checkmark$ Per capita energy consumption: the higher the per capita energy consumption, the more developed a country's industry and economy.

$\checkmark$ Urbanization rate, enrolment rate in secondary education: if the school enrolment rate, urbanization rate and life expectancy are increasing in a country then it is said that the country is developing economically, as these indicators are considered positively related to economic development.

$\checkmark$ Infant mortality: if a country has a high infant mortality then we say that this country is less developed, as this indicator is negatively related to economic development. The higher this indicator the less developed the country

$\checkmark$ Percentage of starch in total calories consumed: if there is a high percentage of starch consumed in total calories consumed by the population, the economy is considered underdeveloped.

$\checkmark$ Sustainable development

Sustainable development is a term widely used by politicians, but it is also a new notion and as such is still being revised and expanded as a concept. The concept of "sustainable development" was first introduced at the United Nations Conference in Stockholm in 1972. The Stockholm Declaration was created in the first principle of which it was stated: man is both the creator and the destroyer of its environment, which nourishes it and gives it the opportunity for intellectual, moral, social and spiritual growth. Over the last 10 years the concept of sustainable development has become more complete and more measurable. sustainable development is "development that meets the needs of the present without compromising the ability of future generations to meet their own needs" (World Commission on Environment and Development-OCED).

A recent World Bank study defined sustainable development as "a process of managing an asset portfolio to maintain and enhance the opportunities that people face." For development to be sustainable, economic, social and environmental objectives (environmental sustainability) must be met in parallel. Achieving these objectives certainly requires careful management. Assets in this definition refer not only to physical capital, but also to natural and human capital. To be sustainable, development must ensure that all of these assets increase over time, or at least do not decline.

To achieve a sustainable development a society should not only meets the needs of the present but also should not compromise the ability of future generations to meet their own needs.

This generational balance is impossible to achieve if there is a lack of social equality today, or if the economic activity of some people harms or endangers the wellbeing of some other people. For example the effect that some industries bring to the 
atmosphere, which affect global warming and create opportunities in this way for some countries to be flooded and impoverished. Sustainable development can also be called "equality and balance" because not only the interests between generations must be balanced, but also within the same generation in three major areas: economic, social and environmental. If one of these objectives is ignored we can ignore development.

A sustainable economic system must be able to produce goods and services continuously, maintain stable and manageable levels of public debt and budget deficit, and eliminate extreme inequalities between sectors that harm agricultural production and industrial. A sustainable economic system means: economic growth, economic efficiency and economic stability. An environmentally sound system must maintain a stable resource base, avoid overuse of renewable resources, and use non-renewable resources only when there is no other alternative. Sustainable environmental system means a healthy environment, rational use of resources and protection of depleted resources.

A sustainable social system should have as its primary goal equality in distribution and opportunity, adequate social services, education and health, gender equality, full employment, security, cultural identity, education, responsibility and political participation.

But let's see what are the places with the happiest people in the world? The international magazine Forbes has ranked as the happiest countries for 2020: Finland, Denmark, Switzerland, Iceland and Norway. As we see all are countries with high economic development but the reverse is not true, not all countries with high economic growth are happy, we are conceiving out that happiness depends more on social and psychological factors rather than economic factors.

A developed country meets many criteria that make the population of that country happy, but again people in themselves will not feel happy even though the country may be very developed, this is because human nature is built in such a way that requires more and more. the poor in a developed country will certainly have state support with food compensation or assistance, but if these poor are compared to those who have a very good life they will feel inferior and feel again dissatisfied with themselves.

\section{REFERENCES}

1. Declaration of the United Nations Conference on the Human Environment, 1972

2. Tatjana P. Soubbotina (2004) Beyond Economic Growth

3. 3.https://www.forbes.com/sites/laurabegleybloom/2020/03/20/ranked-20-happiestcountries-2020/?sh=8ac024b78503 